\title{
Marketing Strategy of Imported Beers before Liquor Liberalization
}

\author{
Sinee Sankrusme \\ Department of International Business, Ramkhamhaeng University, Bangkok, Thailand \\ E-mail: sinee7@gmail.com
}

Received: November 25, 2011 Accepted: January 17, 2012 Published: June 1, 2012

doi:10.5539/ijms.v4n3p45 URL: http://dx.doi.org/10.5539/ijms.v4n3p45

\begin{abstract}
These are the case study analysis of imported beer companies: the C.V.S Syndicate Company and the TIS Worldwide Marketing (1997) Company. The purpose of the study is to analyze marketing strategy and marketing mix of imported beers before liquor liberalization in 2000. The qualitative and descriptive approaches to the case study analysis used standard research methodology. The results of the study indicated (1) Marketing strategy depended on the economic situation, (2) The company's marketing objectives were to gain market share and to respond to consumer demand, (3) Marketing strategy was brand strategy. In addition, the company conducted an investigation into marketing strategy and marketing mix strategy, in areas such as product price, promotion and distribution.
\end{abstract}

Keywords: Marketing strategy, Imported beer, Liquor liberalization

\section{Introduction}

Concerning imported beers, there were: (1) TIS Worldwide Company, an importer of Budweiser beer from the USA, and (2) The C.V.S. Syndicate Company, an beer importer of Miller from USA and Corona from Mexico. The C.V.S. Syndicate Company was a company in affiliation with the Boon Rawd Company which produced Singha beer.

Anheuser Busch Inc., located in St. Louis, Missouri state, USA, began to produce Budweiser beer in 1876 using hop, barley and the best rice for beer production. American Budweiser became the best selling beer worldwide and was given the nickname "King of Beers." In 1997, the TIS Worldwide Marketing (1997) Company started importing Budweiser beer for distribution in Thailand. Sales in 1999 were approximately $15 \%$ higher than in 1988 (the target had been set at $18 \%$ ). In 2000 a target was set to increase sales by $15-20 \%$ from the previous year.

The imported beer market accounted for less than $1 \%$ of the total beer market, which had a value of approximately 50,000 million baht. The company's share of the imported beer market was approximately 5-7\%, the value of which was calculated to be calculated to be 25-35 million baht per year.

The company imported Budweiser beer in order to increase the alternatives available to customers and to respond to the demands of some groups of customers. The target groups were B+ new generation young adults who had enough disposable income to buy Budweiser beer, students from Europe and the USA who were studying in Thailand, and other people who knew and favored Budweiser beer. In the summer, Budweiser beer achieved excellent sales and on occasions it was necessary to import beers from the Philippines, and even a variety of brands from various other countries such as Germany, in order to satisfy demand. However, Budweiser beer was ordered from the USA only. Previously, the company's policy had been to establish a Budweiser brewery in Thailand. However, this policy had to be abandoned when the economic crisis and the floating of baht currency occurred in Thailand.

\section{Objectives}

To analyze the case study of the C.V.S Syndicate Company and the TIS Worldwide Marketing (1997) Company before liquor liberalization in 2000 as following:

1) To analyze marketing objectives

2) To analyze marketing strategy at company level

3) To analyze marketing mix 


\section{Methodology}

Case study methodology was used in the study. The case study was the C.V.S Syndicate Company and the TIS Worldwide Marketing (1997) Company. Data collection took a qualitative approach. In-depth interviews were conducted with key people and experts in the beer business. The primary data was gathered from direct answers to specific questions. The secondary data was gathered from textbooks, journals, dissertations, newspapers, newsletters and seminars etc. The framework of the studies were case study of the C.V.S Syndicate Company which distributed beer brand namely Miller from the USA and Corona from Mexico while the TIS Worldwide Marketing (1997) Company which distributed Budweiser beer from the USA (Figure 1).

\section{Findings}

\subsection{Marketing Strategy of Imported Beers}

Imported beers had very small amount of market-share in comparison with total beers. Marketing activity related to imported beers was conducted by a few companies such as the TIS Worldwide Company and the C.V.S. Syndicate Company. There was no activity at all that was conducted by other companies.

Regarding imported beers, mass market would not be conducted due to having little sales volume. Marketing would be made by conducting a promotion on premise as it was not a mass market. Since prices of imported beers would be high, promotion would be rather limited. The details of imported beer marketing strategy companies are as follows:

\subsection{The C.V.S. Syndicate Company}

\subsubsection{Marketing Objective}

The company's marketing objectives were: (1) The company conducted marketing activities by stressing on consumer orientation for bigger market share, (2) By taste was being conducted for imported beers of the company presenting to company salespersons and major shops to let target customer groups show their opinions and to let company bring product to make further quality improvement.

\subsubsection{Marketing Strategy}

The strategy of the marketing plan is contained in a summary statement showing how the business will achieve its objectives. Effective strategies usually tell management what paths to follow for several key operating variables (Dalrymple \& Parsons, 1990, p. 827).

The number of competitors in the imported beer market increased. Beers imported by the company accounted for approximately $1 \%$ of the whole imported beer market. Beers produced domestically were more widely available than imported beers. The C.V.S. Company imported Miller Draft and Miller Lite beer from the USA and Corona from Mexico.

In a period when the Thai economy was booming, beer was sold in large volumes. Many shops would stock a large quantity of beers. The company promoted sales by advertising in various media, such as television, radio, newspapers and magazines. As a result consumer spending on beer in various places of entertainment increased with little regard to prices. People frequently visited places of entertainment as three times a week (Friday, Saturday and Sunday), and they consumed a large number of bottles.

During the period of economic slowdown in Thailand (from the middle of 1997 onwards), shops would only stock a small quantity of beer. According to statistical data of the Ministry of Finance, sales dropped to $40 \%$ between 1997 and 1999. In the meantime consumer behavior changed. Expenditure on extravagant products, such as the consumption of expensive beers, decreased. The typical number of bottles consumed in a session dropped from three to just one. Night time visits to places of entertainment were cut from three times a week (Friday, Saturday and Sunday) to just one day a week (Saturday or Sunday), and so forth.

The behavior of group $\mathrm{C}$ consumers changed. For example, people who had previously drunk imported beers turned to foreign beers produced domestically, such as Heineken, instead. Although the company lost a proportion of group C customers during the period of economic slowdown, it was not a policy of the company to reduce prices in order to attract group $\mathrm{C}$ back, due to the fact that group A and B customers still liked to drink imported beers. Strategy adjustment by the company during the period of economic slowdown was made by conducting trade promotions directly with agents, shops and customers.

However, during this period of economic slowdown, promotion policy in the beer market was indirect contrast to the state of the economy. This was because in the domestically produced beer market there was intense competition between several principal and new beer players such as Singha, Chang, Heineken etc. In the 
meantime, promotion of imported beers could not be stopped for fear of customers being misled into thinking that the company had ceased trading. It was therefore necessary for the company to carry on promotional activity, in order to show customers that our brand still existed, and this was conducted continuously. The company reduced such advertising budget by about $10 \%$.

During the period of economic slowdown, the parent company (Grupo Modelo) provided assistance towards the advertising budget on a yearly basis, while the company created advertising plans specifying expenditure and target. In addition, assistance was given through the delivery of trading media.

\subsubsection{Marketing Mix Strategy}

The marketing mix principles (also known as the 4P's) are used by businesses as tools to assist them in pursuing their objectives. The marketing mix principles are controllable variables, which have to be carefully managed and must meet the needs of the defined target group. The mix is a part of an organization's planning process and consists of analyzing the defined product strategies, price strategies, place strategies, and promotion strategies (Loudon et al. 2005, pp. 195-196).

\subsubsection{Product Strategy}

Defining the characteristics of a product or service to meet the customers' needs. A product can be seen as the entire bundle of satisfaction that is offered by a marketer to the marketplace (Schewe \& Smith, 1983, p.241).

Product considerations enter into all major company decisions. What products are produced, for example, affects investment decisions, since these deal with the facilities needed to make products, while those concerned with recruitment and training must consider the tasks that supplying products will impose on the business. It is for such reasons that Ansoff (1965) makes product policy the major strategic focus for the firm and regards finance, personnel and production strategies as emanating from basic product.

The company was being sounded out by companies producing many different brands of foreign liquors, to be a principal agent for the distribution of imported liquors. Accordingly, prior to making a decision to import beers and accept being an agent of any brands, the following criteria had to be considered by the company: (1) Import costs had to be taken into consideration, (2) Competitiveness within the import market and other competitors, (3) Whether the policy of the parent company would be supportive, and (4) Marketing research. This last criterion was conducted by holding tasting tests, initially by letting company employees offer tasting at key outlets, aiming at the target groups and letting them give their opinions on the quality of the beers.

The company was an agent of the imported beer brands Miller and Corona, which were well-known brand names among Group A and B customers and had increased sales by up to $85 \%$ in Mexico. It could be said that Corona beer had a good image.

Corona Extra: Corona Extra was a Mexican beer which gained great popularity within a short time in several countries such as the USA, Canada, Australia and New Zealand. It had a readily identifiable taste and drinking style, produced by inserting a wedge of lime or lemon into the neck of the bottle; Corona Extra beer then drunk directly from the bottle, producing a really good taste. During 1998-1999 the company distributed Corona Extra beer, which was calculated to be $65-70 \%$ of the imported beers (1999 calculated to be $60 \%$ of the imported beers). The company started importing Corona Extra beer in 1991 as a premium beer with a strength of $4.6 \%$, and costing 150 baht for a 330cl bottle (excluding value-added tax). The purpose was to provide Thai people with a chance to drink a good tasting beer and to compete with Budweiser beer. According to statistical distribution data, it was able to sell Corona Extra beer in large volumes from the first order.

Corona Extra beer was now the most popular beer in the domestic market, and was the second most popular imported beer in the USA.

Looking for the secret that is satisfied by the unique taste using several methods:

- Take 1 lemon and Corona Extra beer, one bottle to begin with.

- Cut the lemon into quarters (Then keep $3 / 4$ of it for three more Corona Extra beers to follow later)

- Press a $1 / 4$ lemon into a bottle of very cold Corona Extra beer

- Twist the lemon in the neck of the bottle with a clean thumb, and then turn the bottle upside down. Drink directly from the bottle and get ready to be satisfied by Corona Extra beer.

For Corona beer, the company tried to create an image by putting emphasis on drinking with lime to produce a very delicious taste. It could be done by opening the bottle top and then drinking straight from the bottle. Even ladies could open the bottle and drink immediately without appearing improper. In addition, the company created 
the image that a drinker of Corona beer was a well- educated and wealthy person. The company simply stimulated consumers to have an awareness of Corona beer and to remember constantly that it was a kind of beer that had an accompanying lemon. For this reason, there was always to be a picture of a lemon on the label of Corona beer bottles. The beer brand was to be targeted at customers in groups A and B, young working adults who earned an income of more than 10,000 baht a month, were meticulous when selecting beers for drinking, and who drank Corona beer for relaxation.

Miller Genuine Draft was a kind of beer that was produced from natural raw materials without any contaminating substances. It was produced by using proper ingredients such as malted barley, select cereal grains, pure water and choicest hops

Miller Genuine Draft beer contained 5\% alcohol (by volume) and was a high quality beer with an excellent taste, was brewed in accordance with USA beer standards, and had 1/3 of the market share in the USA. It was a draft beer contained in a transparent bottle and it introduced a new method in beer production called the cold filtered method, by which it was not necessary to use pasteurization with heat in order to keep the beer fresh without having to be stored in a refrigerator or using special packaging. Details relating to products, selling point, target group, market segment, product position, brand setting, brand building and brand philosophy were shown in Tables 1,2 , and 3 .

\subsubsection{Price Strategy}

Price is one of the four major variables a marketing manager controls. Price level decisions are especially important because they affect both the number of sales a firm makes and how much money it earns (McCarthy \& Perreault, 1993, p. 500).

The principal factor for the company in determining the selling price was the cost of importing the product. Other factors were miscellaneous expenses and rates of import tax.

Generally, it was not the policy of the company to increase the prices of beers unreasonably. For example, during the period of the Thai primary economic crisis, the company did not adjust the prices of beers upwards and agreed to absorb increased costs. However, when it was necessary to increase prices the following principles would be followed: (1) The company would increase prices only when it was necessary, (2) Prices would not be increased frequently, and (3) As import tax accounts for $65 \%$ of the cost, any increase in import tax would give rise to an increase in the product price (Table 4).

In establishing prices, there were several factors that the company had to consider with regard to competitors. Generally, it was not the company's policy to adjust prices, preferring instead to use the methods of sales promotion and advertising for marketing purposes.

Therefore, although the company was sounded out by several foreign agents about becoming an agent for many brands of beer, the company would not consider importing cheap beers, but various other factors would be taken into consideration, namely (1) Taste of beers, (2) Competition situation in import markets, (3) Competitors, (4) What level of support would be received from the parent company, and (5) Import costs.

\subsubsection{Promotion Strategy}

Promotion is one of the four elements of marketing mix (product, price, promotion, distribution). It is the communication link between sellers and buyers for the purpose of influencing, informing, or persuading a potential buyer's purchasing decision earns (Dalrymple \& Parsons, 1995, pp. 842-844).

The types of promotion to be employed by the company would not only emphasize stimulating customers to know the products, but also aim to increase sales figures. The purpose was to concentrate on creating brand image by encouraging selling activity and focusing on promotion to access target groups. Promotion of Corona and Miller beer could be described as follows:

- Arranged major promotions in large shops which were well known to the public, main department stores and various other shops, such as playing games and setting questions for customers joining in the games.

- During some periods of time, direct promotion programs for Corona and Miller beer would be held in shops, such as customers buying in large quantity receiving a special discount. For example, buying 3 bottles would generate a premium and customers who bought six bottles would receive a premium plus one extra bottle.

Miller was a beer that was imported from the USA, and promotion would focus on drinking for recreation. Promotional activity centred on sponsoring sports events and letting players drink for recreation. Advertising would be through the utilization of various media such as television, radio, magazines, including promotion in shops and to consumers as shown in Table 5. 
The proportion of advertising budget to promotional activity was 30:70. Promotion would be conducted via distribution channels. Since the customers responded to promotion activities for motivation to buy.

Advertising: Advertising budget of Miller and Corona beer were shown in Table 6 and Table 7. Since 1995 until 1999, most of the budget was for TV advertising, meanwhile, in Table 7, it provided interesting information; in 1996-1998, the company spent a big amount in TV, and then suddenly it shifted the budget to radio in 1999-2000 because of cheaper advertising.

\subsubsection{Place (of Distribution) Strategy}

For product-focused companies, establishing the most appropriate distribution strategies is a major key to success, defined as maximizing sales and profits. Unfortunately, many of these companies often fail to establish or maintain the most effective distribution strategies earns (McCarthy \& Perreault, 1993, pp. 45-46).

The company distributed beers to agents and customers directly in the Bangkok Metropolis region and the provinces, by delivering the products to a distribution center in each region belonging to the Boon Rawd Brewery Company. For example, the centers for distribution to customers in the Northern part and Southern part of the country would be Chiang Mai and Surat Thani respectively, as the C.V.S Syndicate Company was affiliated to the Boon Rawd Brewery Company.

The proportion of beer distribution to Bangkok and the provinces was 70:30. The channels of distribution in Bangkok were agents, pubs, restaurants, hotels and trade centers in the proportion 20, 40, 15, 10, and 15 percent respectively, while in the provinces they were pubs, hotels, supermarkets and retail shops in the proportion 80 , 10,5 , and 5 per cent respectively (Figure 2).

Customers were able to purchase with cash or on credit, and while retail prices were not different, the company provided margin of approximately $10-15 \%$ for customers buying in large quantities, and for cash payments it would give a discount of approximately 5-7\%. For buying on credit, the company would allow 15 days for customers who had good credit, so as to create a favorable relationship.

Regarding the eligibility of agents, the company used the standards and principles of the Boon Rawd Brewery Company; for example, it was important that they sold only the products of the Boon Rawd Brewery Company and its affiliated companies, and did not sell products of other companies. In some places of entertainment, such as RCA on Ratchadapisek Road and in the Patpong area, the company assigned agents to take responsibility for sales because of the round-the-clock opening hours, if they had a good relationships with customers.

\subsection{TIS Worldwide Marketing (1997) Company}

Looking at the overseas beer market, one company that imported beers was the C.V.S Syndicate Company, which was in affiliation with the Boon Rawd Brewery Company. The company imported Miller and Corona beers, whose sales were the highest amongst imported beers. Another company was the TIS Worldwide Marketing (1997) Company. This company imported Budweiser beer from the USA, which had the second highest sales figures.

In 1997, the first year that the TIS Worldwide Marketing (1997) Company imported Budweiser beer, the Thai economy faced critical problems including the floating of the baht, which resulted in an increase in the costs of imports and raw materials. It was necessary for the company to increase prices by approximately $1-2 \%$ because it was not company policy to use a pricing strategy. The company solved the problems caused by the impact of the economic crisis in Thailand by accelerating the increase in sales volume and by cutting extravagant expenses to reduce production costs. However, there was no policy to discharge employees or to cut salaries as this might have led to a loss of morale and working incentive, and the company wanted existing employees to continue working for the company.

The company weighed up the importance of marketing operations which would promote the Budweiser beer through advertising. This would involve sponsoring televised international heavyweight boxing, pinpointing target groups through magazine advertising, being involved in aggressive market operations and establishing sales teams who would place beers through principal channels such as on premise: pubs, bars, nightclubs and so on, which other importing beer companies did not do. The reasons were: (1) A desire to increase sales amount, (2) Weighing up the importance of brand image, and (3) Budweiser beer was seeking a joint venture to establish a brewery in Thailand.

Although Thailand was faced with an economic crisis in the middle of 1997, the company was able to distribute beers satisfactorily, to retain regular customers who liked to drink Budweiser beer and to progressively extend distribution channels. 


\subsubsection{Marketing Objective}

The company's marketing objectives were: (1) An 18\% share of the imported beer market in 2000, (2) Satisfying the demand of groups of people such as students who had graduated from abroad and persons who had worked overseas.

\subsubsection{Marketing Strategy}

Marketing strategy is a process that can allow an organization to concentrate its limited resources on the greatest opportunities to increase sales and achieve a sustainable competitive advantage (Baker, 2008, p. 3). A marketing strategy should be centered around the key concept that customer satisfaction is the main goal. Marketing strategy is concerned with finding sustainable ways for organizations to complete in a continuously changing world (Dalrymple \& Parsons, 1995, p.59).

The TIS Worldwide Marketing (1997) Company, was an importer and distributor of Budweiser beer from the USA which used brand strategy in its marketing strategy as follows:

Brand strategy: The company imported Budweiser beer from the USA for distribution in Thailand, concentrating on generating brand name, expanding its scope to make the public aware of Budweiser beer, the creation of brand image by sponsorship of sports such as the televised world heavyweight boxing championship, and using other media such as newspapers. 4P's strategy in conducting marketing was used as follows:

\subsubsection{Marketing Mix Strategy}

McCarthy and Perreault (1993) identified the 4P's of the marketing mix: product, price, promotion, and place (of distribution). In order to achieve marketing objectives it was required to have a strategy that includes different elements - the various parts of the marketing mix.

\subsubsection{Product Strategy}

Businesses facing such marketing and competitive conditions are often product-oriented or production-oriented. They focus most of their attention and resources on functions such as product and process engineering, product and finance in order to acquire and manage the resource necessary to keep pace with growing demand (Mullins et al., 2008, p. 37).

The company started importing Budweiser beer from the USA in 1997. The target group was B + customers, consumers who have purchasing power with sufficient disposable income to be able to afford such purchases. These were mainly customers in pubs and well-known restaurants appealing to young adult customer groups, new generation individuals who had good taste and liked new things at a high price.

The purposes of importing Budweiser beer were: (1) To respond to the needs of consumers who had previously studied or work ed abroad, such as in Europe or the USA, especially students who studied abroad and returned home in summer, and who usually drank and favored this beer, (2) To offer alternatives to Thai people, (3) To establish a Budweiser brewery in Thailand in accordance with company policy (which was put on hold when Thailand faced an economic crisis in 1997), and (4) To build a wider marketing base, by finding new groups of customers and to increase the number of customers such as by opening Budweiser booths at festivals in beer gardens in order to introduce beers to new customers, who would try and get to know Budweiser beer.

The company conducted market research tests from time to time to study consumer behavior, leading to improved quality and established market policies. According to the research, brand loyalty of Budweiser customers was high due to the favoring the mild taste and good quality. Existing customers were always found, and the company wished to promote their beers to a new generation, who would have a chance to sample and favor Budweiser beer. The company had focused on the quality of Budweiser beer as being an important factor in achieving this. The company was sure of the quality and brand image of Budweiser beer for the following reasons:

Budweiser beer used an excellent barley malt to which specially extracted rice grains were added. This was combined with hops from Europe and America, together with a mixture of yeast and pure water.

Budweiser beer was fermented for a full 30 days and was inspected meticulously for quality, so that a taste and flavor with an individual identity was created, which gave rise to the most perfect beer with a mild taste. Budweiser beer finally went through a filtering process, which was called "Chill Proofing", in order to dissolve and remove proteins that cause the beer to appear cloudy. 


\section{Properties of Budweiser's Beer}

1) Budweiser was a high quality beer. All its ingredients are natural, which gave Budweiser a superior quality to other brands.

2) Budweiser is a clean, fresh and new beer, whose taste makes it suitable for consumption by any beer drinker until they are satisfied.

3) Budweiser is a beer which is recognized as being a classic American brand. Budweiser has an image and reputation of class in the American style.

4) Budweiser is a brand that has a good reputation in the areas of quality and worldwide standard. Most people like to drink Budweiser rather than other brands.

The company's products were shown in Table 8 while brand setting, brand building, and brand philosophy was presented in Table 9.

\subsubsection{Price Strategy}

Pricing goods and services is a critical job in the successful operation of for profit and not-for-profit organizations. Price is the element of the marketing mix that generates revenue; the rest are costs (Dalrymple \& Parsons, 1995, p. 531).

It was not the policy of the company to conduct market operations through price adjustments. However, it was sometimes necessary for the company to increase prices by approximately $1-2 \%$ due to: (1) Floating of the value of the baht, making import costs higher than previously, and (2) Adjustments to the excise tax on liquors imported from overseas.

Regarding the principles for setting the selling price, the company considered various factors: (1) Importing cost, (2) Tax, (3) Transport, (4) Promotion and advertising, (5) Other expenses such as expenditure for administration and marketing, (6) Competitors, and (7) Marketing situation and others.

Tax was a major cost. Usually, the company would set the wholesale price to be similar to imported beers of other brands. Selling prices would see the addition of transport cost, packaging cost, etc. The company would deliver beers to Bangkok and provincial agents and collect cash in the terminal. The company discounted $3 \%$ for cash purchases and provided 15 day credit for modern trade.

The company gave a discount to agents for mass purchasing. For example, amounts of 100 crates and 50 crates would be discounted $10 \%$ and $5 \%$ respectively.

With regard to the margin for agents, each outlet would make their own addition themselves. Generally, marketing mechanisms would be followed. Shops might calculate reasonable margins, but the selling price would be close to other brands. Foreign liquor agents had to be granted permission from The Excise Department. Generally, agents and provincial wholesalers would be the one and the same. Due to the fact that amount of Budweiser beer sales was very small, there was no controversy.

\subsubsection{Promotion Strategy}

Promotion is communication information between seller and potential buyer or others in the channel to influence attitudes and behavior. The marketing manager's main promotion job is to tell target customers that the right product is available at the right lace at the right price (McCarthy \& Perreault, 1993, p. 418).

Generally, promotion and advertising of imported beers would be very limited. But in this case the company's policy was to import Budweiser beer, which was a high quality and good tasting beer from the USA, it to the Thai people, who would then get to know and favor it, leading to widespread consumption. For the purpose of establishing a marketing base for Budweiser in Thailand, it was planned by the company to establish a Budweiser brewery in Thailand. The company therefore carried out promotion and advertising, as the Thai market had a high rate of growth. The proportion of promotion to advertising was 60: 40 .

Promotion: The company emphasized promotion principally at selling spots. The company arranged sales teams to assist in arranging promotional activity for agents, shops and at various festivals. In addition, there were free offers such as glasses for consumers who bought Budweiser.

Beer garden festivals were held such as the Budweiser beer garden at Siam Center Building (SCB), Ratchada road, for which the opening ceremony was presided over by His Excellency the Ambassador of the USA to Thailand, and which was overwhelmingly popular with consumers. The initial target was 20 tables but in the end more than 100 tables were utilized. 
The beer market in Thailand was regarded as one of the most important in the South East Asia region. Because of this the parent company continually provided full support for marketing operations, supported Budweiser promotional activity in order to maintain channels of distribution, extended the range of the market and created brand image for this famous premium-level world class beer by supporting various sports events and through advertising as follows:

Advertising: The company advertised Budweiser beer continuously. The purpose was to make the beer brands widely known in Thailand via various media such as television, newspapers, magazines and cinemas (Table 10).

In 1994 and 1997, advertising in newspapers contributed the greatest proportion, at $72.60 \%$ and $65.21 \%$ respectively. The reasons were that the cost of newspaper advertising was low compared to television, messages and pictures could be spread countrywide and so forth, especially in 1998 which was a period of economic crisis in Thailand, which meant that the company increasingly had to cut down on expenses.

Television advertising was mainly shown on UBC. It promoted Budweiser beer by publicizing the brand and giving it an image appealing to Thai people as much as possible. In particular, the company frequently sponsored world heavyweight boxing tournaments. In 1999 and 2000, for example, the highest proportion of the advertising budget was allocated to television, with figures of 100 percent and 75.95 percent respectively. The reason was that television advertising produced good results with regard to increasing sales volumes by making consumers aware of the Budweiser name rapidly.

\subsubsection{Place (of Distribution) Strategy}

Place strategy is the element of a firm's decision-making concerned with developing an efficient and effective means of storing and handling finished products and of getting them efficiently to the target market (Mullins et al., 2008, p. 238).

Channels of distribution of Budweiser beer were concerned mainly with Thai students who had returned from Europe and the USA, Thai people who worked abroad, and also with the summer period. When Thai students returned home for visits, sales of Budweiser would be particularly high.

Major channels of distribution were modern trading establishments such as trade centers, major department stores such as Carrefour and The Mall, and renowned 5 star hotels such as Dusit Thani, Sheraton, Erawan and Oriental, because most of their consumers recognised the brand and knew the taste of Budweiser well. In addition, the Company distributed beers via agents in Bangkok and the provincial region (Figure 3).

\section{Conclusion}

There are two case studies of imported beer companies in this study. The first one is case study of the C.V.S Syndicate Company which was an affiliated company of the Boon Rawd Brewery Company. The company was a beer importer of Miller from the USA and Corona from Mexico. The 4P's strategy was conducted as follows:

Product strategy: Tasting tests were conducted on the company's imported beers, presented by salespersons in major shops, to let target customer groups give their opinions and to allow the company to make further quality improvements to the products.

Price strategy: The company would not increase the prices of the beers, unless it was absolutely necessary. In the event of costs increasing, a price adjustment would be made once only, so that the price remained constant for as long as possible.

Promotion strategy: Promotions were organized, such as providing a special discount, sponsorship of sports events and arranging games at major trade centers, to attract target groups through television coverage. Advertising was done using television, radio, magazines and so on.

Channel strategy: The products were sent by the company to agents in the Bangkok region and in the provinces.

The second case study is the TIS Worldwide Marketing (1997) Company. The company started importing "Budweiser" from the USA in 1997 and conducted brand strategy and the 4P's strategy as follows:

Product strategy: Marketing research was conducted and tasting were sometimes held to study consumer behavior and improve the quality.

Price strategy: The company would set the price so as to be close to the prices of other imported beers.

Promotion strategy: Promotion was principally conducted at points of sale. Sales teams would be dispatched by the company to assist promotional activities for agents and shops. The handing out of promotional material, such as glasses for consumers of Budweiser beer, was also employed, as was frequent sponsorship of world heavyweight boxing tournaments. 
Advertising: This was done via media such as television, newspapers, magazines, and cinemas.

Channel strategy: Principal channels of distribution were modern trade establishments (Trade centers, department stores) and hotels that had a good reputation. In addition, the company distributed products via agents in Bangkok and the provinces.

\section{Acknowledgement}

I wish to express my appreciation to Mr. Thon Kawinanan, Managing Director of the TIS Worldwide Marketing (1997) Company who provided extensive specialized assistance with the imported beer information. His suggestions were invaluable and helped me in many ways. Special thanks must go to Mr. Karn Prejapanij, Marketing Director of the C.V.S. Syndicate Company who gave his time freely and lent his support in order to complete the study. Of course, much appreciation is due to the many people who were kind enough to provide information concerning the imported beers. My thanks to all. In addition, dozens of people were kind enough to be instrumental in making this study a reality. My thanks to all.

\section{References}

Ansoff, H. (1965). Corporate Strategy. New York: McGraw-Hill.

Baker, Michael. (2008). The Strategic Marketing Plan Audit.

Dalrymple, Douglas J., \& Parsons, Leonard, J. (1990). Marketing Management: Strategy and Cases. New York: John Wiley \& Sons.

Dalrymple, Douglas J., \& Parsons, Leonard, J. (1995). Marketing Management. New York: John Wiley \& Sons.

Loudon, David, Stevens, Robert \& Wren, Bruce. (2005). Marketing Management: Text and Cases. New Delhi: Atlantic Publishers and Distributors.

McCarthy, E., Jerome, Perreault, Jr., \& William D. (1993). Basic Marketing. Boston: Irwin.

Mullins, John W., Walker Jr., Orville C., \& Boyd Jr., Harper. (2008). Marketing Management: A Strategy Decision Making Approach. Boston: McGraw Hill Irwin.

Schewe, Charles, D., \& Smith, Reuben, M. (1983). Marketing: Concepts and Applications. New York: McGraw-Hill.

Table 1. Products of C.V.S. Syndicate Company

\begin{tabular}{|c|c|c|c|c|c|}
\hline Brand & $\begin{array}{c}\text { Year of } \\
\text { Launching }\end{array}$ & $\begin{array}{c}\text { Alcohol } \\
\text { Content / } \\
\text { Proof }\end{array}$ & $\begin{array}{c}\text { Purpose of } \\
\text { Launching }\end{array}$ & $\begin{array}{c}\text { Producer } \\
\text { Company }\end{array}$ & $\begin{array}{c}\text { Exporter } \\
\text { Country }\end{array}$ \\
\hline Corona Extra & 1991 & 4.6 & $\begin{array}{l}\text { - Consumer Demand } \\
\text { - Purchasing Power Ability }\end{array}$ & $\begin{array}{c}\text { Grupo } \\
\text { Modelo }\end{array}$ & Mexico \\
\hline Miller Draft & 1994 & 5 & - Demand for USA beer & $\begin{array}{c}\text { Miller } \\
\text { Brewing } \\
\text { Co., Ltd }\end{array}$ & USA \\
\hline Miller Lite & 1994 & 4 & -Demand for USA beer & $\begin{array}{c}\text { Miller } \\
\text { Brewing } \\
\text { Co., Ltd }\end{array}$ & USA \\
\hline
\end{tabular}

Table 2. Selling point, target group, market segment and product positioning

\begin{tabular}{|c|c|c|c|c|}
\hline Brand & Selling Point & Target Group & Market Segment & $\begin{array}{c}\text { Product } \\
\text { Positioning }\end{array}$ \\
\hline Corona Extra & $\begin{array}{c}\text { Premium } \\
\text { Relaxation Beverage }\end{array}$ & $\begin{array}{l}\text { Age: } 25-35 \\
\text { Income: Over } \\
20,000-30,000 \\
\text { baht/ month } \\
\text { Education: Over } \\
\text { Bachelor Degree }\end{array}$ & $\begin{array}{l}\text { Woman: Group } \\
\text { A+ to B+ } \\
\text { Executive }\end{array}$ & $\begin{array}{l}\text { Overseas } \\
\text { experienced } \\
\text { person }\end{array}$ \\
\hline Miller & $\begin{array}{l}\text { Imported beer from } \\
\text { USA }\end{array}$ & Similar to Corona & $\begin{array}{c}\text { Focus on } \\
\text { sportsmen }\end{array}$ & $\begin{array}{c}\text { Dealing with } \\
\text { USA }\end{array}$ \\
\hline
\end{tabular}


Table 3. Brand setting, brand building, and brand's philosophy

\begin{tabular}{|l|l|l|}
\hline \multicolumn{1}{|c|}{ Brand } & \multicolumn{1}{|c|}{ Brand Setting } & \multicolumn{1}{c|}{ Brand Building } \\
\hline \multirow{3}{*}{ Corona Extra } & International Brand & - Drink with lime \\
& & $\begin{array}{l}\text { - Drink from bottle } \\
\text { - Advertise through radio and } \\
\text { magazines }\end{array}$ \\
\hline Miller Draft & & - Testing spot \\
\hline
\end{tabular}

Table 4. Prices of C.V.S. Syndicate Company

\begin{tabular}{|c|c|c|c|}
\hline Brand Name & Packaging & $\begin{array}{c}\text { Size } \\
\text { (Liter) }\end{array}$ & $\begin{array}{c}\text { Wholesale Price } \\
(2000)\end{array}$ \\
\hline Corona Extra & Bottle & 330 C.C. & $\begin{array}{c}1,800 \text { baht/case* } \\
\text { (Net including VAT) }\end{array}$ \\
\hline Miller Draft & Bottle & 350 C.C. & $\begin{array}{c}1,350 \text { baht/case* } \\
\text { (Net including VAT) }\end{array}$ \\
\hline Miller Lite & Bottle & 350 C.C. & $\begin{array}{c}1,350 \text { baht/case* } \\
\text { (Net including VAT) }\end{array}$ \\
\hline
\end{tabular}

Remark: $* 1$ case $=12$ bottles

Table 5. Promotion of the C.V.S. Syndicate Company

\begin{tabular}{|c|l|}
\hline Type & \multicolumn{1}{|c|}{ Promotion } \\
\hline Corona & $\begin{array}{l}\text { - Television, radio, newspapers, magazines. } \\
\text { - Arrange game playing programs with shops, trade centers. } \\
\text { - Target groups A, B who have income more than 10,000 baht a month. } \\
\text { - Shop and consumer promotion }\end{array}$ \\
\hline Miller & $\begin{array}{l}\text { - Television, radio, magazines etc. } \\
\text { - Sports marketing } \\
\text { - Shop and consumer promotion }\end{array}$ \\
\hline
\end{tabular}

Table 6. Miller genuine draft beer's advertising

(Thousand Baht)

\begin{tabular}{|c|c|c|c|c|c|c|c|}
\hline Year & TV & Radio & Press & Magazine & Out-door & Cinema & Total \\
\hline 1994 & - & $\begin{array}{c}349 \\
(25.16 \%)\end{array}$ & $\begin{array}{c}1,038 \\
(74.84 \%)\end{array}$ & - & - & - & $\begin{array}{c}1,387 \\
(100 \%)\end{array}$ \\
\hline 1995 & $\begin{array}{c}8,538 \\
(61.47 \%)\end{array}$ & $\begin{array}{c}4,448 \\
(32.02 \%)\end{array}$ & $\begin{array}{c}824 \\
(5.93 \%)\end{array}$ & $\begin{array}{c}80 \\
(0.58 \%)\end{array}$ & - & - & $\begin{array}{c}13,890 \\
(100 \%)\end{array}$ \\
\hline 1996 & $\begin{array}{c}7,547 \\
(56.81 \%)\end{array}$ & $\begin{array}{c}3,852 \\
(29.00 \%)\end{array}$ & $\begin{array}{c}999 \\
(7.52 \%)\end{array}$ & $\begin{array}{c}727 \\
(5.47 \%)\end{array}$ & $\begin{array}{c}160 \\
(1.20 \%)\end{array}$ & - & $\begin{array}{c}13,285 \\
(100 \%)\end{array}$ \\
\hline 1997 & $\begin{array}{c}2,570 \\
(61.73 \%)\end{array}$ & $\begin{array}{c}722 \\
(17.34 \%)\end{array}$ & $\begin{array}{c}200 \\
(4.80 \%)\end{array}$ & $\begin{array}{c}671 \\
(16.13 \%)\end{array}$ & - & - & $\begin{array}{c}4,163 \\
(100 \%)\end{array}$ \\
\hline 1998 & $\begin{array}{c}181 \\
(77.68 \%)\end{array}$ & - & - & 30 & - & 22 & 233 \\
$(12.88 \%)$ & - & - & - & - & $106 \%)$ \\
\hline 1999 & 106 & - & - & - & - & - & - \\
\hline 2000 & - & - & - & & & & \\
\hline
\end{tabular}


Table 7. Corona extra beer's advertising budget by all media (1989 - 2000)

(Thousand Baht)

\begin{tabular}{|c|c|c|c|c|c|c|c|}
\hline Year & TV & Radio & Press & Magazine & $\begin{array}{c}\text { Out- } \\
\text { Door }\end{array}$ & Cinema & Total \\
\hline 1992 & - & - & $\begin{array}{c}543 \\
(81.53 \%)\end{array}$ & $\begin{array}{c}63 \\
(9.46 \%)\end{array}$ & $\begin{array}{c}60 \\
(9.01 \%)\end{array}$ & - & $\begin{array}{c}666 \\
(100 \%)\end{array}$ \\
\hline 1993 & - & - & $\begin{array}{c}377 \\
(51.64 \%)\end{array}$ & $\begin{array}{c}353 \\
(48.36 \%)\end{array}$ & - & - & 730 \\
$(100 \%)$
\end{tabular}

Source: Media Data Resources Company

Table 8. Products of TIS Worldwide Company

\begin{tabular}{|c|c|c|c|c|}
\hline Brand & Year of Launch & Type of Product & $\begin{array}{c}\text { Producer } \\
\text { Company }\end{array}$ & $\begin{array}{c}\text { Exporter } \\
\text { Country }\end{array}$ \\
\hline Budweiser & 1997 & Premium & $\begin{array}{c}\text { Anheuser-Busch } \\
\text { Inc. }\end{array}$ & USA \\
\hline
\end{tabular}

Table 9. Brand setting, brand building and brand's philosophy

\begin{tabular}{|c|c|c|c|}
\hline Brand & Brand Setting & Brand 's Philosophy & Brand Building \\
\hline Budweiser & International Brand & King of Beers & Advertising \\
\hline
\end{tabular}

Table 10. Budweiser beer's advertising budget by media

(Thousand Baht)

\begin{tabular}{|c|c|c|c|c|c|c|c|}
\hline Year & $\mathrm{TV}$ & Radio & Press & Magazine & Outdoor & Cinema & Total \\
\hline 1994 & - & $\begin{array}{c}840 \\
(21.59 \%)\end{array}$ & $\begin{array}{c}2,824 \\
(72.60 \%)\end{array}$ & $\begin{array}{c}226 \\
(5.81 \%)\end{array}$ & - & - & $\begin{array}{c}3,890 \\
(100 \%)\end{array}$ \\
\hline 1995 & $\begin{array}{c}16,008 \\
(51.07 \%)\end{array}$ & $\begin{array}{c}11,591 \\
(36.98 \%)\end{array}$ & $\begin{array}{c}1,498 \\
(4.78 \%)\end{array}$ & $\begin{array}{c}2,222 \\
(7.09 \%)\end{array}$ & - & $\begin{array}{c}27 \\
(0.09 \%) \\
\end{array}$ & $\begin{array}{l}31,346 \\
(100 \%)\end{array}$ \\
\hline 1996 & $\begin{array}{c}9,333 \\
(35.67 \%)\end{array}$ & $\begin{array}{c}7,216 \\
(27.58 \%)\end{array}$ & $\begin{array}{c}5,786 \\
(22.11 \%)\end{array}$ & $\begin{array}{c}2,424 \\
(9.26 \%)\end{array}$ & $\begin{array}{c}511 \\
(1.95 \%) \\
\end{array}$ & $\begin{array}{c}898 \\
(3.43 \%) \\
\end{array}$ & $\begin{array}{l}26,168 \\
(100 \%)\end{array}$ \\
\hline 1997 & - & - & $\begin{array}{c}253 \\
(65.21 \%)\end{array}$ & $\begin{array}{c}135 \\
(34.79 \%)\end{array}$ & - & - & $\begin{array}{c}388 \\
(100 \%)\end{array}$ \\
\hline 1998 & - & - & - & - & - & - & - \\
\hline 1999 & $\begin{array}{c}343 \\
(100.00 \%)\end{array}$ & - & - & - & - & - & $\begin{array}{c}343 \\
(100 \%)\end{array}$ \\
\hline 2000 & $\begin{array}{c}1,180 \\
(75.95 \%)\end{array}$ & - & - & $\begin{array}{c}373 \\
(24.02 \%)\end{array}$ & - & - & $\begin{array}{c}1,553 \\
(100 \%) \\
\end{array}$ \\
\hline
\end{tabular}

Source: Media Data Resources Company 


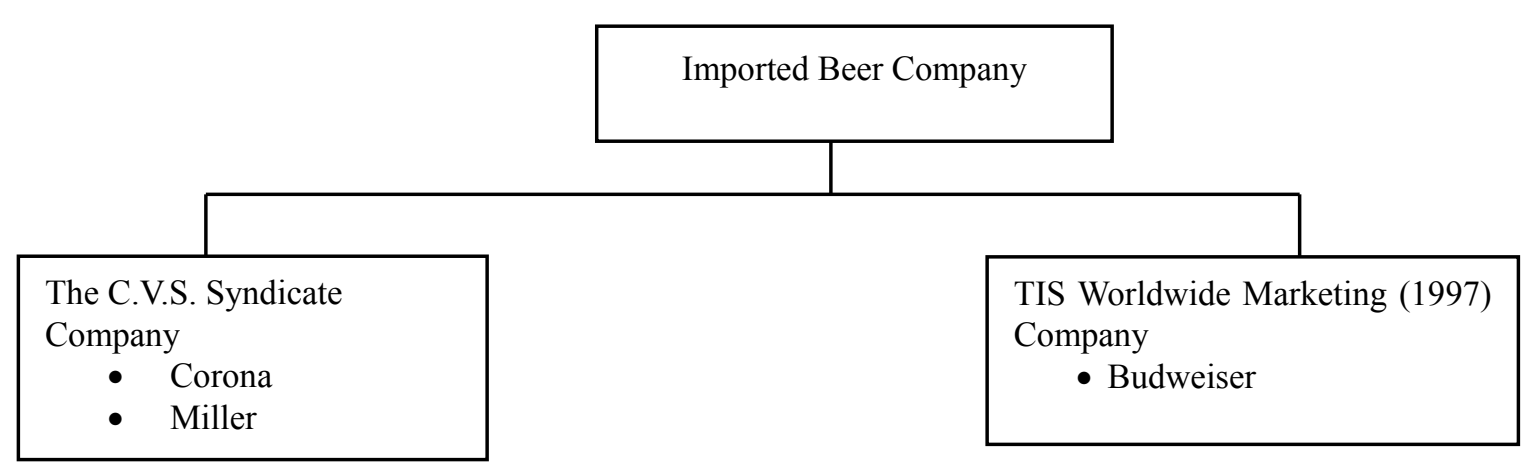

Figure 1. Framework of the study

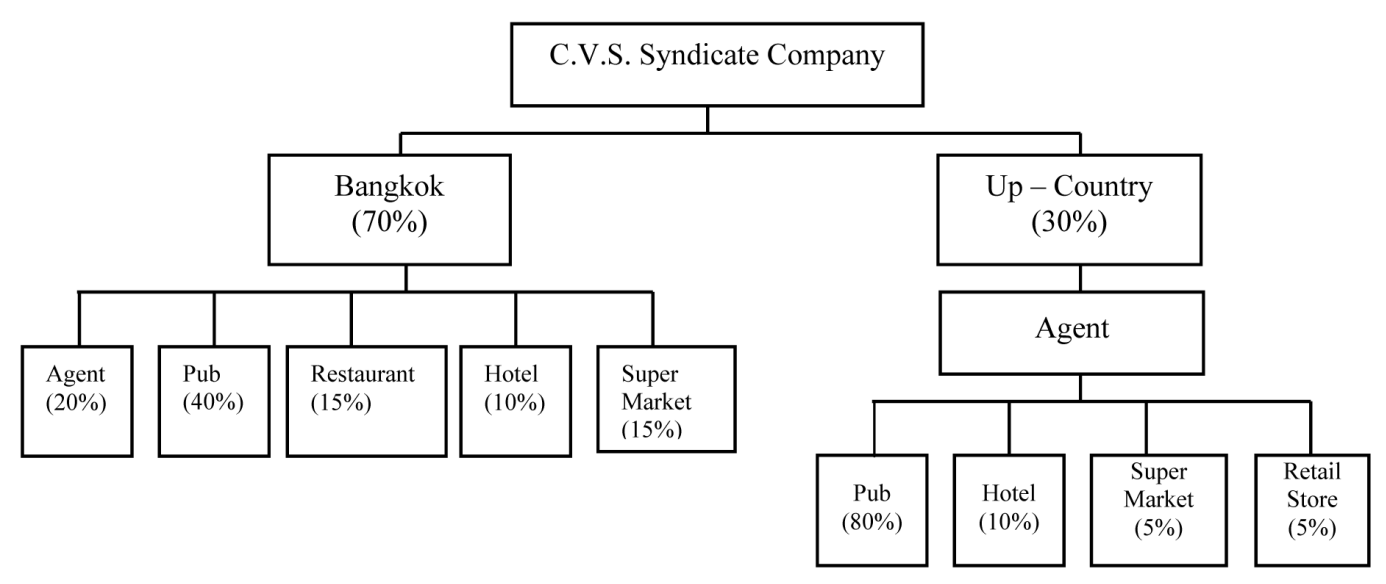

Figure 2. Channel structure of C.V.S. Syndicate Company 


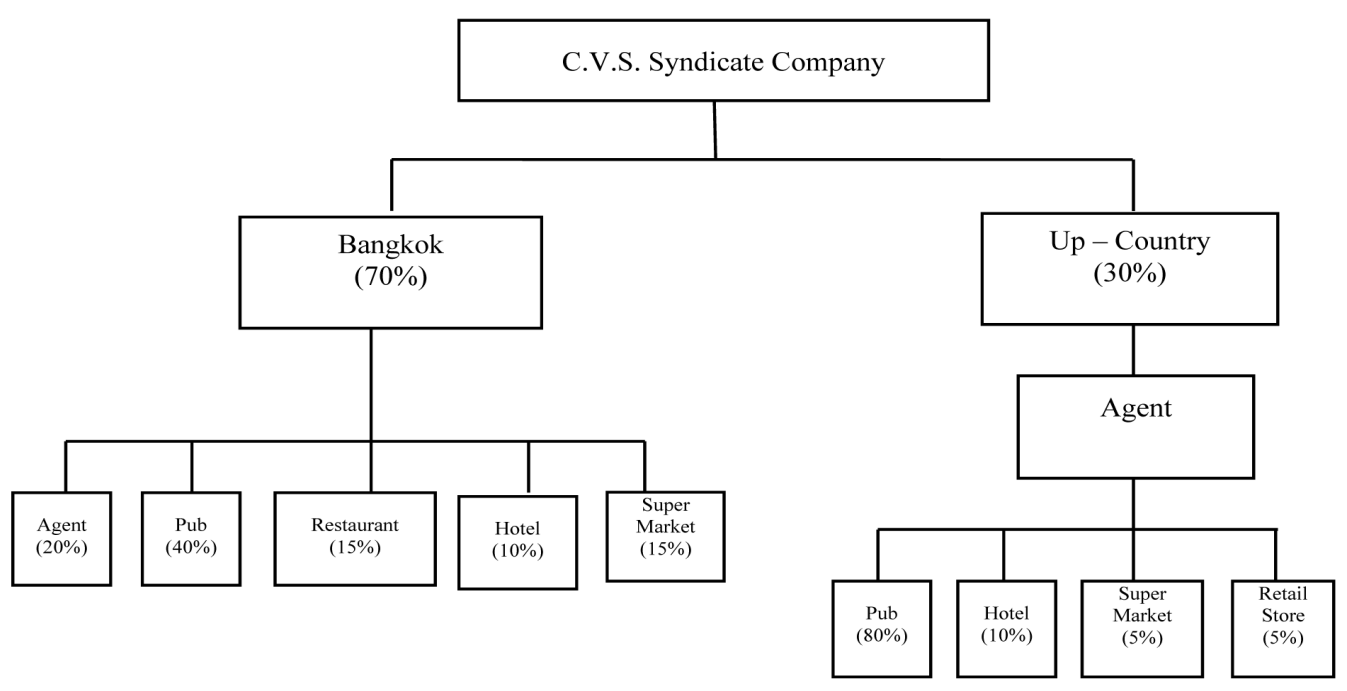

Figure 3. Channel structure of TIS Worldwide Marketing (1997) Company

Remarks: F = Food Shop

$$
\begin{aligned}
& H=\text { Hotel } \\
& E=\text { Place of Entertainment } \\
& \mathrm{R}=\text { Retail Shop }
\end{aligned}
$$

